\title{
CMAJ in changing times
}

Previously published at www.cmaj.ca on July 20

A s of July 20, you may have noticed major improvements to cmaj.ca. Our redesign of the website signals a significant focus on electronic publishing. This is part of the next step in making CMAJ a top international general medical journal. We hope to serve the needs of our broad readership including physicians, academic leaders and researchers from both Canada and the international medical community.

We also wish to highlight a number of additional successes this year. Based on an ambitious vision, we have recruited a team of well-trained senior editors and subsequently increased the number of submissions from 1769 articles in 2006 to an expected 2500 in 2009, as well as increased the number of published research articles by $30 \%$. Our impact factor is now 7.5, the highest it has ever been. We have also increased the number and diversity of clinical reviews. CMAJ is now on target to provide more knowledge that matters to our core audience of researchers and clinicians. All of these successes have been made possible by a commitment and costly investments by the Canadian Medical Association (CMA) in our editorial staff. These investments have paid dividends as we strive to assist authors in publishing work that will influence clinical practice and public policy. ${ }^{1}$

However, CMAJ, one of the most recognizable and valued benefits of CMA membership, is facing significant financial challenges. Like most other print media, we have seen a dramatic drop in our advertising revenue. As a consequence, the editorial team supports the decision of the owners and publisher to decrease the number of print issues of CMAJ this coming year to cut costs.

Going forward, we plan to invest in a more robust presence on the Web. Our journal of record is already cmaj.ca. We are in the process of transforming CMAJ to become a true Web-based journal. In the past, like most other medical journals, cmaj.ca was merely the vertical representation on a computer screen of the horizontal pages of the print CMAJ. Freed from the constraints of the printed page, we can take advantage of the speed, flexibility, interactivity and other procedures available through electronic publishing. The change is happening faster than we had anticipated, but it is in keeping with our long-term vision for the journal.

In the coming weeks, cmaj.ca will differ from the print version both in the frequency with which we publish and the way we present articles. We will now publish articles as soon as they are ready, instead of every 2 weeks. You can expect new content almost every day.

Medical information that sits in steel drawers or on a hard drive delays the translation of knowledge to action. The Web allows us to minimize this delay. Reducing the amount of paper we use also allows us to be more eco-friendly.

Losing our traditional funding source has created difficulties for us, but it has also forced us to look at alternatives. The editorial team views this financial threat to $C M A J$ as an opportunity for change. The medical community has grown accustomed to pharmaceutical advertising paying for its medical journals as the industry pays for other forms of continuing medical education. Despite elaborate mechanisms designed to minimize the influence of commercial interests on research and clinical recommendations in published material, we cannot escape the perception of bias and influence. Perhaps dramatic decreases in display advertising will create incentives to develop new business opportunities, leading to diversified revenues and decreasing the chance of pharmaceutical influence.

The constant throughout these changes is our high editorial standards. Our editorial brain trust, our peer reviewers and editing staff are CMAJ's source of credibility. ${ }^{1}$

So, how will these changes affect our print readers? From this time forward, we will only print a subset of what we publish on the Web. This year, we will print 3 fewer issues, and we will reduce our print run in 2010 . We will also move toward publishing shorter articles in print and the longer versions on the Web. We realize that the print version will always have a special place for our Canadian readers. We do not have plans to abandon print altogether. However, most readers — 25 million around the globe — already rely on the electronic version of $C M A J$ as their primary source of its information. As the Web version flourishes, the print copy of the CMAJ will, we expect, continue to enjoy a niche in the comfort of our readers' favourite armchair.

Many members of the CMA are not aware that CMAJ has historically only received a small portion of their annual membership fee. This small contribution worked well because, for 20 years, pharmaceutical advertising paid for the rest of the costs and even contributed about $\$ 13$ million in profits to the CMA and its members. Going forward, the full potential of CMAJ and cmaj.ca will only be realized with the support of CMA members. You can comment by sending an email to cmajweb@cmaj.ca. Or you can mail us an old-fashioned letter. If you have suggestions to improve $C M A J$, in print or online, we want to hear from you.

\section{Paul C. Hébert MD MHSc \\ Editor-in-Chief \\ CMAJ}

With the Editorial-Writing Team (Matthew B. Stanbrook MD $\mathrm{PhD}$, Ken Flegel MDCM MSc, Noni MacDonald MD MSc, Amir Attaran LLB DPhil and Laura Eggertson BA)

Competing interests: See www.cmaj.ca/misc/edboard.shtml.

\section{REFERENCE}

1. Sox HC. Medical journal editing: Who shall pay? [Editorial] Ann Intern Med 2009; 151:68-9. 